\title{
Aromatase Activity in Brain and Pituitary of Immature and Mature Atlantic Salmon (Salmo salar L.) Parr
}

\author{
E. Andersson, ${ }^{*}$ B. Borg, ${ }^{*}$ AND J. G. D. Lambert $\dagger$ \\ *Department of Zoology, University of Stockholm, S-106 91, Stockholm, Sweden; and tDepartment of \\ Experimental Zoology, University of Utrecht, Padualaan 8, Utrecht $3584 \mathrm{CH}$, The Netherlands
}

Accepted June 27, 1988

\begin{abstract}
Brain homogenatcs from Atlantic salmon parr converted tritiated androstencdione to testosterone, estrone, and $17 \beta$-estradiol. The formation of estrogens was markedly higher in homogenates of whole brains from mature parr males than from immature parr males. The highest estrogen synthesis was found in the telencephalon and diencephalon. In both of these parts the estrogen production was higher in mature males than in immature males. There was no difference in estrogen formation by pituitaries from immature female and immature male parr, whereas the formation of estrogens and testosterone was higher in the mature male parr. 1988 Academic Press, Inc.
\end{abstract}

The Atlantic salmon, Salmo salar, is an anadromous fish. The young females and some of the young males migrate to the sea in a sexually immature state and return to the river for spawning after a few years. Some of the young males, however, mature already as parr and may breed at a small size, without having left the river. It is not known if and in what respects the neuroendocrine feedback control of the pituitary gonadotropic (GTH) cells differs between the two categories of parr males. Androgens can be aromatized to estrogens in the brains of most vertebrates. This conversion is particularily high in teleosts (Callard, 1982). Aromatization has been indicated as being of importance for androgen effects on the GTH cells in the young rainbow trout, Salmo gairdneri (Crim et al., 1981) and in the adult African catfish, Clarias gariepinus (de Leeuw et al., 1986). The object of the present study was to investigate this component in the neuroendocrine system in mature and immature Atlantic salmon parr. To that end brain homogenates and pituitaries from mature and immature Atlantic salmon parr were incubated with tritiated androstenedione and the steroids formed were analyzed.

\section{MATERIAL AND METHODS}

Animals. Two-summer-old Atlantic salmon parr of the Umeälven river stock were used in this investigation. The fish were kept at the Norrfors hatchery situated at the river Umeälven $\left(64^{\circ} \mathrm{N}\right)$ Sweden in $2 \times 2-\mathrm{m}$ tanks supplied with through-flowing river water and at natural photoperiod. The fish were fed on EWOS salmon food. Mature and immature parr were dissected on the 14-15 of September, 1987. At this time the mature males had started to produce running milt and had a gonadosomatic index (GSI) ranging from 8.9 to $14 \%$ (mean GSI was $11.2 \%$ ). The gonads of the immature males were thread-like and were too small for meaningful weighing (GSI $\approx 1 \%$ ). RIA measurements of androgens from fish taken at this occasion gave mean levels of $5 \mathrm{ng} / \mathrm{ml}$ of 11 -ketotestosterone and 2 $\mathrm{ng} / \mathrm{ml}$ testosterone in mature parr and $0.4 \mathrm{ng} / \mathrm{ml} 11$ ketotestosterone and $1 \mathrm{ng} / \mathrm{ml}$ testosterone in immature parr (I. Mayer and R. Schulz, unpublished).

Preparation of samples for incubation. After decapitation, the brains were removed and immediately frozen in plastic tubes on dry ice and stored at $-70^{\circ}$. The brains were homogenized in whole or in parts with Teflon-glass homogenizers at $0^{\circ}$ in $0.1 \mathrm{M}$ phosphate buffer (pH 7.4) containing $0.25 \mathrm{M}$ sucrose.

Chemicals. $7-\left[{ }^{3} \mathrm{H}\right]$ Androstenedione $(7.6 \mathrm{Ci} / \mathrm{mmol})$ was purchased from Radiochemical Centre, Amer- 
sham. The purity was controlled by thin-layer chromatography (TLC). Unlabeled steroids were obtained from Merck A.G.; NAD and NADPH were from Boehringer. All chemicals and solvents were of analytical grade.

Incubations. All incubations were carried out for 3 hr at ca. $20^{\circ}$ in open tubes under continuous shaking. The $7-\left[{ }^{3} \mathrm{H}\right]$ androstenedione was first dissolved in propylene glycol (final concentration 5\% brain parts, $17 \%$ whole brains), which was mixed with K-phosphate buffer $(0.1 M, \mathrm{pH} 7.4)$, with nicotinamide adenine dinucleotide (NAD, $2 \mathrm{~m} M$ ) and reduced nicotinamide adenine dinucleotide phosphate (NADPH, $2 \mathrm{mM}$ ) added. The final steroid concentration was $0.13 \mu M$ or $1.0 \mu \mathrm{Ci} / \mathrm{ml}$ (except for the whole brains, $0.12 \mu \mathrm{M}, 0.9$ $\mu \mathrm{Ci} / \mathrm{ml})$.

Homogenates of whole brains and brains divided into major parts from mature and immature males were incubated in final volumes of $3 \mathrm{ml}$ (whole brains) or $1.5 \mathrm{ml}$ (brain parts).

Pituitaries were incubated individually in a volume of $0.07 \mathrm{ml}$. Pooled pituitaries, 15 from mature and 15 from immature, were both incubated in a final volume of $0.2 \mathrm{ml}$.

Analysis. The enzyme reactions were terminated by adding dichloromethane. Before extraction with dichloromethane the carriers androstenedione, testosterone, estrone, and estradiol were added. The tritium activity in the water fraction was determined with scintillation counting as described by Schoonen and Lambert (1986).

The combined organic extracts were evaporated and the residue was subjected to TLC on glass plates precoated with silica gel F254 (Merck) in saturated tanks, first three times in toluene-cyclohexanc, 1:1 (system 1) to separate apolar compounds from steroids. The steroids remained localized on the base line. Consecutive TLC using diisopropylether-chloroformhexane, 7:2:1 (3×) (system 2), separated the steroids. After development the carriers were located by uv absorption at $240 \mathrm{~nm}$. The percentages of activity in dif- ferent peaks on the TLC plates were determined using a Berthold LB2842 automatic TLC linear analyzer.

The areas corresponding to testosterone, estrone, and estradiol from some of the material were eluted and subjected to TLC using chloroform-ethanol, 95:5 (1X) (system 3). Testosterone, estrone, and estradiol formed by the brain from a mature male and by the pooled pituitaries from mature males were acetylated, rechromatographed in disopropylether-chloroform-hexane, 7:2:1 (1X), and recrystallized to a constant specific activity as described by Schoonen and Lambert (1986).

\section{RESULTS}

By far most of the activity was found in the organic fraction. Only ca. $2 \%$ (highest value $4 \%$ ) of the total activity was found in the water fraction.

The radiochromatograms after TLC in system 2 of the organic fraction from both the brain homogenate and the pituitary incubations showed peaks at the positions of the carriers androstenedione $\left(\Delta^{4}\right)$, testosterone $(\mathrm{T})$, estrone (E1), and $17 \beta$-estradiol (E2). The identity of the formed T, E1, and E2 was confirmed successively by TLC in system 3 , acetylation, and a rerun in system 2 , and by recrystallization to a constant specific activity (Table 1). It was found that the T, E1, and E2 areas after a first separation in TLC system 2 contained no significant amounts of other radiolabeled substances. For this reason the amounts of $T$, $\mathrm{E} 1$, and $\mathrm{E} 2$ formed were calculated from these scanograms. There were also peaks

TABLE 1

Identification of Steroids Formed from Androstenedione by Brain and Pituitaries

\begin{tabular}{lcrrrr}
\hline & & \multicolumn{3}{c}{ Specific activity $(\mathrm{dpm} / \mathrm{mg})$} \\
\cline { 3 - 6 } Tissue & Steroid & Original & 1. Cryst. & 2. Cryst. & 3. Cryst. \\
\hline \multirow{2}{*}{ Brain } & T & 126,467 & 116,481 & 124,023 & 124,208 \\
& E1 & 36,642 & 35,312 & 36,057 & 36,063 \\
& E2 & 87,347 & 87,171 & 87,509 & 85,548 \\
Pituitary & T & 7,558 & 7,446 & 6,993 & 7,291 \\
& E1 & 10,109 & 9,139 & 10,144 & 9,748 \\
& E2 & 4,405 & 4,123 & 4,324 & 4,169 \\
\hline
\end{tabular}

Note. $\mathrm{dpm}=$ disintegrations per minute; $\mathrm{T}=$ testosterone; $\mathrm{E} 1=$ estrone; $\mathrm{E} 2=17 \beta$-estradiol. 
of unknown substances in the scanograms from both pituitary and brain incubations. The largest and most distinct of the unknown peaks from the homogenates of whole brains was found at a distance from the baseline two-thirds of that of $\mathrm{T}$. It was larger in the scanograms from mature (12.8 $\pm 1.3 \%$ of organic fraction activity) than from immature brains $(6.6 \pm 0.4 \%)$. This peak was not present in the pituitary scanograms.

The results of the incubations of brains from immature and mature males are shown in Table 2. The yields of E1 and E2 were much higher in the mature than in the immature fish, whereas the opposite was the case with $\mathrm{T}$. The percentages of both $\mathrm{E} 1$ and E2 were more than twice as high in all mature fish than in any of the immature ones. The estrogens $(E 1+E 2)$ constituted on an average $45 \%$ of the organic fraction from the mature brains and $13 \%$ from the immature brains. This corresponds to an aromatization of 159 and $45 \mathrm{pmol}$ radiolabeled androgen/incubation, or 1.7 and 0.4 $\mathrm{pmol} / \mathrm{mg}$ brain weight, respectively. The lower yield of $\mathrm{T}$ in the incubations of brains from the mature $(27 \%)$ ) than from the imma-

TABLE 2

Steroid Conversion in Homogenates of Whole Brains from MATURE AND IMMATURE SALMON PARR

\begin{tabular}{lcc}
\hline & Mature & Immature \\
\hline$n$ & \multicolumn{1}{c}{8} & 7 \\
Body weight $(\mathrm{g})$ & $25.6 \pm 1.8$ & $30.6 \pm 1.7$ \\
Brain weight $(\mathrm{mg})$ & $96 \pm 3$ & $105 \pm 3$ \\
Androstenedione $(\%)$ & $10.1 \pm 2.0$ & $16.1 \pm 2.5$ \\
Testosterone (\%) & $26.6 \pm 3.0$ & $58.4 \pm 2.6$ \\
Estrone (\%) & $16.2 \pm 1.1$ & $4.7 \pm 0.3$ \\
17 $\beta$-Estradiol $(\%)$ & $28.7 \pm 1.7$ & $8.0 \pm 0.3$ \\
E1 + E2 & & \\
$\quad$ (pmol/mg brain wt) & $1.67 \pm 0.10$ & $0.43 \pm 0.02$ \\
\hline
\end{tabular}

Note. Means and standard errors shown. Amount of steroids in percentage of total activity in organic fraction. The percentages of estrone, estradiol, and testosterone and the formation of $\mathrm{E} 1+\mathrm{E} 2 / \mathrm{mg}$ brain wt are different between the two groups. $P<0.001$ in all four comparisons, Mann-Whitney $U$ test. ture fish $(58 \%)$ is perhaps partly due to the higher formation of estrogens. The combined yield of $\mathrm{T}$ and $\mathrm{E} 2$, both formed by a $17 \beta$-hydroxysteroid dehydrogenase conversion, is $55 \%$ in the mature and $66 \%$ in the immature ones.

When parts of a mature male brain were incubated a high synthesis of estrogens was found in the telencephalon and in the ventral diencephalon. A lower aromatization was found in the tectum opticum/dorsal diencephalon area, whereas the cerebellum and brainstem were practically negative. All parts showed considerable T formation. The results of individual incubations of telencephalon, ventral diencephalon ("diencephalon"), tectum opticum/dorsal diencephalon ("tectum") from mature and immature males are shown in Table 3. The tectum yields of $\mathrm{T}, \mathrm{E} 1$, and $\mathrm{E} 2$ were about the same in mature and immature brains. In both telencephalon and diencephalon the yields of E1 and E2 were much higher (3-7 times) in the mature than in the immature ones. The yield of $\mathrm{T}$ was higher in the immature than in the mature ones, but these differences largely disappeared when the weights of the brain parts were considered. The average synthesis of radiolabeled estrogens via aromatization in the tectum was $0.3 \mathrm{pmol} / \mathrm{mg}$ in mature and $0.2 \mathrm{pmol} / \mathrm{mg}$ in immature fish, in the diencephalon it was $1.6 \mathrm{pmol} / \mathrm{mg}$ in mature and $0.2 \mathrm{pmol} / \mathrm{mg}$ in immature, and in the telencephalon it was $11.8 \mathrm{pmol} / \mathrm{mg}$ in mature and $2.0 \mathrm{pmol} / \mathrm{mg}$ in immature fish brains.

The yields of T, E1, and E2 in incubations with individual pituitaries from mature male parr and immature male and female parr are shown in Table 4 . There was no difference between immature males and females. All three substances were formed in larger amounts by the pituitaries from the mature than from the immature fish.

\section{DISCUSSION}

Homogenates of salmon brains con- 
TABLE 3

Steroid Conversion in Homogenates of Brain Parts from Mature and Immature Salmon Parr

\begin{tabular}{lcccccc}
\hline & $\begin{array}{c}\text { Weight } \\
(\mathrm{mg})\end{array}$ & $\Delta^{4}(\%)$ & $\mathrm{T}(\%)$ & E1 (\%) & E2 (\%) & $\begin{array}{c}\text { E1 + E2 } \\
(\mathrm{pmol} / \mathrm{mg})\end{array}$ \\
\hline Mature 1 & & & Telencephalon & & & \\
Mature 2 & 5.1 & 7.6 & 49.6 & 16.1 & 15.6 & 12.3 \\
Immature 1 & 6.5 & 5.6 & 44.0 & 22.8 & 14.3 & 11.3 \\
Immature 2 & 7.3 & 14.9 & 68.0 & 5.0 & 4.0 & 2.4 \\
& 6.4 & 10.9 & 73.9 & 3.3 & 2.6 & 1.8 \\
Mature 1 & & & Diencephalon & & & \\
Mature 2 & 18.5 & 9.0 & 63.0 & 12.7 & 3.8 & 1.8 \\
Immature 1 & 24.6 & 12.8 & 60.2 & 12.4 & 4.2 & 1.3 \\
Immature 2 & 34.6 & 17.4 & 72.1 & 1.2 & 1.4 & 0.1 \\
& 30.1 & 17.5 & 67.9 & 2.6 & 0.9 & 0.2 \\
Mature 1 & & & Tectum & & & \\
Mature 2 & 19.6 & 17.4 & 70.5 & 1.7 & 1.4 & 0.3 \\
Immature 1 & 19.0 & 20.7 & 68.2 & 1.5 & 0.9 & 0.2 \\
Immature 2 & 29.6 & 27.1 & 61.8 & 1.4 & 1.8 & 0.2 \\
\hline
\end{tabular}

Note. Individual values. $\Delta^{4}=$ androstenedione; $\mathrm{T}=$ testosterone; $\mathrm{E} 1=$ estrone; $\mathrm{E} 2=17 \beta$-estradiol. Amount of steroids as percentage of total activity in organic fraction.

verted $\Delta^{4}$ to $T$, E1, and E2. This is in agreement with findings in several other teleosts (Callard et al., 1981b; Pasmanik and Callard, 1985; Lambert et al., 1982; Timmers and Lambert, 1987; Timmers et al., 1987; Borg et al., 1987a).

Although most of the $\Delta^{4}$ precursor was converted during the incubations, there was always a considerable amount of aromatizable androgens $\left(\Delta^{4}\right.$ and T) left. The time course of conversion was not studied. However, in the African catfish, C. gariepinus, this conversion is linear for $4 \mathrm{hr}$ with a similar method (Timmers and Lambert, 1987). It was not possible for us to examine the effect, if any, of freezing of the brains. Although the methods used may give some deviation from ideal values (i.e., underestimation), this is hardly of major importance for the comparison of the conversion between different brain areas and between mature and immature fish.

With the reservations above, the aromatase activity in whole brains was ca. 0.6 pmol mg wet $\mathrm{wt}^{-1} \mathrm{hr}^{-1}$ in whole brains of mature parr, and up to ca. $3.9 \mathrm{pmol} \mathrm{mg}^{-1}$

TABLE 4

Steroid Conversion by Pituitaries from Mature Males and Immature Males and Femaifes

\begin{tabular}{lcrrr}
\hline & Fish weight $(\mathrm{g})$ & $\mathrm{T}(\%)$ & $\mathrm{E} 1(\%)$ & E2 $(\%)$ \\
\hline Mature males & $23.5 \pm 1.8$ & $21.9 \pm 1.2$ & $12.2 \pm 0.8$ & $3.6 \pm 0.4$ \\
Immature males & $30.7 \pm 1.6$ & $12.8 \pm 0.9$ & $6.6 \pm 0.3$ & $1.2 \pm 0.1$ \\
Immature females & $31.8 \pm 1.6$ & $11.0 \pm 1.2$ & $6.1 \pm 0.5$ & $1.1 \pm 0.1$ \\
\hline
\end{tabular}

Note. Mean and standard errors shown. $\mathrm{T}=$ testosterone; $\mathrm{E} 1=$ estrone; $\mathrm{E} 2=17 \beta$-estradiol. Amounts of steroids expressed as percentage of activity in the organic fraction. Thirteen fish in each group studied. The amount of testosterone, estrone, and estradiol formed is larger in the mature males than in both immature males and females. $P<0.001$ in all six comparisons, Mann-Whitney $U$ test. 
$\mathrm{hr}^{-1}$ in the brain area with the highest conversion. In the stickleback, Gasterosteus aculeatus, a conversion of ca. 0.1 pmol $\mathrm{mg}^{-1} \mathrm{hr}^{-1}$ was found in the whole brain using similar methods (Borg et al., 1987a). In homogenate incubations of major brain areas from other teleosts the maximum conversions were $1.6 \mathrm{pmol} \mathrm{mg} \mathrm{mo}^{-1} \mathrm{hr}^{-1}$ in the toadfish, Opsanus tau, $3.6 \mathrm{pmol} \mathrm{mg}^{-1}$ $\mathrm{hr}^{-1}$ in the goldfish, Carassius auratus (Pasmanik and Callard, 1985), and $0.1 \mathrm{pmol}$ $\mathrm{mg}^{-1} \mathrm{hr}^{-1}$ in the longhorn sculpin, Myoxocephalus octodecimspinosus (Callard et al., 1981b). Incubations of punches from limited brain areas gave conversions of up to ca. 1 pmol mg-1 $\mathrm{hr}^{-1}$ in the stickleback (Borg et al., 1987a) and up to $3.7 \mathrm{pmol}$

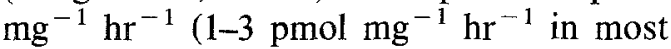
areas in the telencephalon, diencephalon, and mesencephalon) in the African catfish (Timmers et al., 1987). Thus it seems that the aromatase activity in the salmon parr is at least as high, if not higher, than that in other studied teleosts.

The conversion of androgens to estrogens was highest in the telencephalon and also high in the diencephalon. The tectum opticum displayed a lower aromatase activity and the cerebellum and brain stem were practically negative. A high aromatase activity in the diencephalon has also been found in all previously studied teleosts; longhorn sculpin, (Callard et al., 1981b); rainbow trout, $S$. gairdneri (Lambert et al., 1982); goldfish, toadfish (Pasmanik and Callard, 1985); African catfish (Timmers et al., 1987), and three-spined stickleback (Borg et al., 1987a). The aromatase activity in the telencephalon has also been found to be high in sculpin (Callard et al., 1981b), goldfish (Pasmanik and Callard, 1985), and catfish (Timmers et al., 1987), but not in stickleback (Borg et al., 1987a). The tectum opticum/dorsal diencephalon displayed a moderate conversion in the Atlantic salmon. This was also the case in the stickleback (Borg et al., 1987a), whereas the rainbow trout (Lambert et al., 1982) and the catfish (Timmers et al., 1987) had high estrogen formation in these regions. Brain stem-anterior spinal cord and cerebellum had a low conversion in the salmon as in most other studied fishes, except in the toadfish were a high conversion was found in the anterior spinal cord (Pasmanik and Callard, 1985).

The salmon pituitary was also capable of converting androstenedione into estrone and estradiol. A conversion of androgens to estrogens has also been found in other studied teleosts: sculpin (Callard et al., 1981a; Olivereau and Callard, 1985), goldfish and toadfish (Pasmanik and Callard, 1985), catfish (de Leeuw et al., 1985), and stickleback (Borg et al., 1987a).

Comparing the aromatase activity in the brains of mature and immature parr it was found that much more estrogens were formed by homogenates of whole brains from mature parr males than from immature ones. This difference was also found in both telencephalon and diencephalon homogenates. Pituitaries from mature parr males displayed higher estrogen production than pituitaries from immature male and female parr. The brain homogenates from immature parr, however, produced more $\mathrm{T}$ than those from the mature parr.

Changes in brain aromatase activity according the reproductive state have been reported in a number of teleosts. For example, in the sculpin, aromatization changed seasonally in both the hypothalamus and the telencephalon (Callard et al., 1981a). In the stickleback the aromatase activity in the nucleus preopticus-nucleus anterior periventricularis (but not in other regions) is strongly influenced by season (Borg et al., 1987a). It must, however, be pointed out that the steroid conversion in the brain has, to our knowledge, not been studied in completely immature fish before. Thus, we do not know whether the dramatically higher estrogen formation in the mature parr than in the immature ones might be paralleled at puberty in other teleosts. A 
higher aromatase activity in mature than in immature parr was found in both the telencephalon and the diencephalon. 'This suggests that the high conversion in both these regions is indeed connected with reproduction and makes it less likely that the high estrogen formation in teleost brains serves other needs. In mammals, scveral investigations (Callard, 1983; Michnovicz et al., 1987) have shown a particularly high conversion early in ontogeny. However, this is difficult to compare with the present study, where immature and mature fish of the same age have been examined.

A number of studies performed in mammals have shown that only aromatizable androgens and estrogens are effective in stimulating male reproductive behavior, whereas androgens that cannot be converted to estrogens are ineffective (e.g., Beyer et al., 1973). This is often also assumed to be the case in fishes, but experimental evidence is lacking. On the contrary, stimulatory effects of the nonaromatizable androgen 11-ketoandrostenedione on reproductive behavior have been found in the stickleback (Borg, 1987), and preliminary results indicate that this androgen also stimulates male sexual behavior in castrated Atlantic salmon parr (I. Mayer and I. Berglund, unpublished).

As in other vertebrates, aromatization appears to be of importance for negative feedback effects from the gonads on GTH secretion in the African catfish (de Leeuw et al., 1985). A role for aromatase in the feedback systems has also been suggested in the African catfish and stickleback, where its anatomical distribution has been studied in more detail than in other fishes. In these two species the activity is particularly high in hypothalamic regions like the nucleus preopticus and the nucleus lateralis tuberis which probably control the GTH secretion (Peter, 1983). In young salmonids positive effects of steroids on accumulation of GTH in the pituitary have been reported (Crim and Evans, 1979; Crim et al., 1981; Gielen et al., 1982). Crim et al. (1981) found that several aromatizable androgens and estrogens had this effect, whereas nonaromatizable androgens and corticosteroids did not. An aromatase inhibitor partly suppressed the effect of testosterone. Van den Hurk et al. (1984), on the other hand, found that some corticosteroids and nonaromatizable 11-androgens also had stimulatory effects on GTH accumulation, though very much less than the aromatizable methyltestosterone, which was also tested. Ikuta et al. (1987) found the same stimulatory effect of high doses of testosterone and the nonaromatizable 11-ketotestosterone on pituitary GTH content in immature masu salmon, Oncorhynchus masou. The positive effect of androgen on GTH accumulation in young rainbow trout is due to a stimulation on the pituitary level (Făhraeus-van Ree et al., 1983; Gielen and Goos, 1983). Prolonged treatments also lead to elevated GTH levels in the plasma (Crim and Evans, 1983). Only aromatizable androgens have been used in the study of these aspects. The aromatase activity was higher in the pituitaries of the mature parr males than in the pituitaries of immature parr. The difference was, however, proportionally less than in the brain in general and is perhaps not larger than could be accounted for by the probable growth of the GTH cells. In the African catfish, aromatase activily was found to be present in this cell type (de Leeuw et al., 1985).

The higher aromatase activity in the brain of the mature parr males might be related to changes in feedback mechanisms associated with maturation. It is not possible to say if differences in steroid metabolism determine which males will mature and which will not. Preliminary results from incubations with brains sampled in July, when the differentiation of the gonads first becomes visible, show a much smaller and less clear-cut difference between mature and immature males, indicating that this is not the case. Far more detailed studies are, however, needed. There is also the possibility that the gonads are influencing the ar- 
omatase activity. Stimulatory effects of testes/androgens on brain estrogen formation have been found both in mammals (e.g., Roselli and Resko, 1984) and in the stickleback (Borg et al., 1987b).

In the stickleback the testes stimulate an increase in aromatase activity in the nucleus preopticus-nucleus anterior periventricularis region (other brain areas were, however, not influenced) when winter fish are brought to breeding by long photoperiod and high temperature (Borg et al., 1987b). The increased aromatase activity in the brain of the mature parr male might also be due to a stimulation from the gonads. In the stickleback morphological studies indicate that methyltestosterone stimulates the GTH cells in winter (Borg et al., 1986) and have an inhibitory effect when the breeding season has already started (Borg et al., 1985). The feedback from the gonads to the pituitary is largely negative in adult salmonids (e.g., van Putten et al., 1981; Billard et al., 1977). One might speculate that an increased aromatase activity in the brain in the maturing parr might change the general androgen effect on the GTH cells from a positive accelerating to a negative stabilizing feedback.

\section{ACKNOWLEDGMENTS}

Supported by the Swedish Natural Science Research Council and by the Leche foundation, Stockholm. The salmon were supplied and maintained by the staff of the Norrfors salmon hatchery, Umea (Swedish Hydropower Board). We thank Miss J. C. M. Granneman (University of Utrecht) for excellent technical assistance.

\section{REFERENCES}

Beyer, C., Larsson, K., Perez-Palacios, G., and Morali, G. (1973). Androgen structure and male sexual behaviour in the castrated rat. Horm. Behav. 4, 99-108.

Billard, R., Richard, M., and Breton, B. (1977). Stimulation of gonadotropin secretion after castration in rainbow trout. Gen. Comp. Endocrinol. 33, $163-165$.

Borg, B. (1987). Stimulation of reproductive behaviour by aromatizable and non-aromatizable androgens in the male three-spined stickleback, Gasteros- teus aculeatus. Proceedings, Vth Congress European Ichthyologists, Stockholm, 1985, pp. 269 271.

Borg, B., Paulson, G., and Peute, J. (1986). Stimulatory effects of methyltestosterone on pituitary gonadotropic cells and testes Leydig cells of the three-spined stickleback, Gasterosteus aculeatus L., in winter. Gen. Comp. Endocrinol. 62, 54-61.

Borg, B., Reschke, M., Peute, J., and van den Hurk, R. (1985). Effects of castration and androgentreatment on pituitary and testes of the threespined stickleback, Gasterosteus aculeatus L., in the breeding season. Acta Zool. (Stockholm) 66, $47-54$.

Borg, B., Timmers, R. J. M., and Lambert, J. G. D. (1987a). Aromatase activity in the brain of the three-spined stickleback, Gasterosteus aculeatus. I. Distribution and effects of season and photoperiod. Exp. Biol. 47, 63-68.

Borg, B., Timmers, R. J. M., and Lambert, J. G. D. (1987b). Aromatase activity in the brain of the three-spined stickleback, Gasterosteus aculeatus. II. Effects of castration in winter. Exp. Biol. 47, 69-71.

Callard, G. V. (1982). Aromatase in the teleost brain and pituitary: Role in hormone action. In "Reproductive Physiology of Fish" (C. J. J. Richter and H. J. Th. Goos, Eds.), pp. 40-43. Pudoc, Wageningen.

Callard, G. V. (1983). Androgen and estrogen actions in the vertebrate brain. Amer. Zool. 23, 607-620.

Callard, G. V., Petro, Z., and Ryan, K. J. (1981a). Biochemical evidence for aromatization of androgen to estrogen in the pituitary. Gen. Comp. Endocrinol. 44, 359-364.

Callard, G. V., Petro, Z., and Ryan, K. J. (1981b). Estrogen synthesis in vitro and in vivo in the brain of a marine teleost (Myoxocephalus). Gen. Comp. Endocrinol. 43, 243-255.

Crim, L. W., and Evans, D. M. (1979). Stimulation of pituitary gonadotropin by testosterone in juvenile rainbow trout (Salmo gairdneri). Gen. Comp. Endocrinol. 37, 192-196.

Crim, L. W., and Evans, D. M. (1983). Influence of testosterone and/or luteinizing hormone releasing hormone analogue on precocious sexual development in the juvenile rainbow trout. Biol. Reprod. 29, 137-142.

Crim, L. W., Peter, R. E., and Billard, R. (1981). Onset of gonadotropic hormone accumulation in the immature trout pituitary gland in response to estrogens or aromatizable androgen steroid hormones. Gen. Comp. Endocrinol. 44, 374-371.

de Leeuw, R., Smit-van Dijk, W., Zigterman, W. J., van der Loo, J. C. M., Lambert, J. G. D., and Goos, H. J. Th. (1985). Aromatase, estrogen 2hydroxylase, and catechol- $O$-methyltransferase in isolated, cultured gonadotropic cells of mature 
African catfish, Clarias gariepinus (Burchell). Gen. Comp. Endocrinol. 60, 171-177.

de Leeuw, R., Wurth, Y. A., Zandbergen, M. A., Peute, J., and Goos, H. J. Th. (1986). The effects of aromatizable androgens, non-aromatizable androgens, and estrogens on gonadotropin release in castrated catfish, Clarias gariepenus (Burchell): A physiological and ultrastructural study. Cell Tissue Res. 243, 587-594.

Făhraeus-van Ree, G. E., van Vlaardingen, M., and Gielen, J. Th. (1983). Effect of $17 \alpha$-methyltestosterone, estradiol- $17 \beta$ and synthetic LHRH on production of gonadotropic hormone in pituitaries of rainbow trout (in organ culture). Cell Tissue Res. 232, 157-176.

Gielen, J. Th., and Goos, H. J. Th. (1983). The brainpituitary-gonadal axis in the rainbow trout, Salmo gairdneri. II. Direct effect of gonadal steroids on the gonadotropic cells. Cell Tissue Res. 233, 377388.

Gielen, J. Th., Goos, H. J. Th., Peute, J., van den Bosch, R. A., and van Oordt, P. G. W. J. (1982). The brain-pituitary-gonadal axis in the rainbow trout, Salmo gairdneri: Gonadal hormones and the maturation of gonadotropic cells. Cell Tissue Res. 225, 45-56.

Ikuta, K., Aida, K., Okumoto, N., and Hanyu, I. (1987). Effects of sex steroids on the smoltification of masu salmon, Oncorhynchus masou. Gen. Comp. Endorcinol. 65, 99-110.

Lambert, J. G. D., Wilms, P. G., Zandwijk, M. L., Goos, H. J. Th., and van Oordt, P. G. W. J. (1982). Localization of aromatase activity in the brain of the rainbow trout (Salmo gairdneri). In "Reproductive Physiology of Fish" (C. J. J. Richter and H. J. Th. Goos, Eds.), p. 57. Pudoc, Wageningen.

Michnovicz, J. M., Hahn, E. F., and Fishman, J. (1987). 19-Hydroxylation and aromatization of androgens in the developing rat brain. Endocrinology 121, 1209-1214.

Olivereau, M., and Callard, G. (1985). Distribution of cell types and aromatase activity in the sculpin (Myoxocephalus) pituitary. Gen. Comp. Endocrinol. 58, 280-290.

Pasmanik, M., and Callard, G. V. (1985). Aromatase and $5 \alpha$-Reductase in the teleost brain, spinal cord, and pituitary gland. Gen. Comp. Endocrinol. 60 , 244-251.

Peter, R. E. (1983). The brain and neurohormones in teleost reproduction. In "Fish Physiology" (W. S. Hoar, D. J. Randall, and E. M. Donaldson, Eds.), Vol. IXA, pp. 97-135. Academic Press, New York.

Roselli, C. E., and Resko, J. A. (1984). Androgens regulate brain aromatase activity in adult male rats through a receptor mechanism. Endocrinology 114, 2183-2189.

Schoonen, W. G. E. J., and Lambert, J. G. D. (1986). Steroid metabolism in the testes of the African catfish, Clarias gariepinus (Burchell), during spawning season, under natural conditions, and kept in ponds. Gen. Comp. Endocrinol. 61, 40-52.

Timmers, R. J. M., and Lambert, J. G. D. (1987). Measurement of aromatase activity in the brain of the African catfish, Clarias gariepinus-a comparison of two assay methods. Comp. Biochem. Physiol. $B$ 88, 453-456.

Timmers, R. J. M., Lambert, J. G. D., Peute, J., Vullings, H. G. B., and van Oordt, P. G. W. J. (1987). Localization of aromatase in the brain of the male African catfish, Clarias gariepinus (Burchell), by microdissection and biochemical identification. J. Comp. Neurol. 258, 368-377.

Van den Hurk, R., Gielen, J. Th., and Terlou, M. (1984). Accumulation of glycoprotein gonadotropin in the pituitary of juvenile rainbow trout in response to androgens and C21-steroids, including 11-steroids. Cell Tissue Res. 235, 635-642.

Van Putten, L. J. A., Peute, J., van Oordt, P. G. W. J., Goos, H. J. Th., and Breton, B. (1981). Glycoprotein gonadotropin in the plasma and its cellular origin in the adenohypophysis of sham-operated and ovariectomized rainbow trout, Salmo gairdneri. Cell Tissue Res. 218, 439-448. 